\title{
THE PROGRESS OF FORESTRY IN CANADA ${ }^{1}$
}

\author{
By G. P. Burchill \\ President, Canadian Forestry Association
}

A BOUT thirty years ago, a young man, brought up on a farm in my community, became aware of the fact that there was something to be learned about farming and, after much hesitation, decided to take a three months course at the nearest Agricultural College. A few days after he had left home the news got abroad in the community, and a neighboring farmer, an elderly man, met me and said "I hear Jack Jones has gone to Truro to learn how to farm and that it will take three months. Sure a man could learn all there is to know about farming in three hours!"

And so, in 1906, when, as a result of a conference of Canadian citizens interested in the conservation and perpetuation of Canada's forests, in the city of Fredericton, the University of New Brunswick followed the University of Toronto and established a Department of Forestry, securing a Professor from Yale, as one of the few available sources where such a person could be found, the average citizen in our Province, who lives pretty close to the woods, like my friend the farmer, could not understand why a man should go to College if he wanted to go to the woods-Colleges were ordained for Doctors, Clergymen and Lawyers.

We have come a long distance from those days and, with the Universities of Laval and British Columbia conferring degrees in the Science of Forestry, the pioneering group of my days have been joined by an annually increasing number until now the profession numbers about 400 in Canada, who comprise this splendid organization functioning across this widely diversified country through eight sections and joining together in annual convention. And here, I want to pay tribute to the founders of this Society and the Quebec Association of Forest Engineers who have builded better than they knew, for these organizations, bringing you together so that east meets west and providing an opportunity for an exchange of views and experiences, have been a great source of strength and support to the growth of the young profession. As individuals, I also want to express due acknowledgement for services rendered to the Canadian Forestry Association and the Quebec For. estry Association, which functions so successfully under the able leadership of Mr. Omer Lussier, for you have done much to make both these Associations more effective in their appeal. In fact their progress and success, I venture to say, has in a great measure been due to the wise counsel and active co-operation of Canadian forest engineers, members of your associations, always so freely given.

We have also made great progress within the profession itself since those days when a Forester was lucky if he found a government who would experiment with his services. At the present time not only government and timberland executives, but intelligent public opinion recognizes the need of the forest engineer, and the contribution which his science has made and

1. Address delivered at the Annual Banquet, 34th Annual Meeting. Canadian Society of Forest Engineers, Quebec, on January 26, 1942. 
can make to the economic health of the nation. The science itself has not lain dormant down through the years. Where thirty years ago it was a single stream of knowledge, the interval has opened up branches and other springs from the same rock which have broadened the Science to include a wide variety of subjects.

In those days we were branded as theorists but since then theories have been put into practise and our men today are solving such problems as harvesting and transporting wood to mills-Management of forests-while aerial Forest Photography and research in Forest Entomology and many other subjects are included in the day's work. The services of those of you engaged in commercial lines are as yet largely confined to the larger organizations such as the Pulp and Paper Companies, but I see wonderful possibilities for assistance to the farmer and small woodlot holders in the development of extension forestry. Land classification, in my judgment, is one of the most important fields for development in Canada for our agricultural population includes many farmers who are wearing their lives away trying to grow potatoes or grain on land which will only grow trees, but will grow them fast, and all this with vacant farm land available. Moreover, the care and cultivation of the farmer's woodlot is all-important to the agricultural community. With this in view our government in New Brunswick is most sympathetic to the recommendation made by the maritime section and supported by our provincial branch of the Canadian Forestry Association, that an extension forester be employed, and negotiations are now in progress with the University of New Brunswick to work out an arrangement whereby such an official will function under the direction of the Dean and staff of the Department of Forestry at the University, in order that the best technical practices may be employed and all evidence of political favour removed.

Yes, we have come a long way since those days, and conventions such as this are profitable and desirable if they do nothing more than serve as chain stakes in the flight of time to mark the progress of the years and to pause long enough to glance back over the road you have come and endeavor to spot a trail, which will lead to the next pitching ground. Yes, I said "pause", for we are moving at a terrific speed.

In such an age measuring rods lose their value and perspective, as the objectives of yesterday are pitifully inadequate for the demands of the present and the future. And as the momentum increases and our horizons widen, let us be sure, in our haste to get places, that our progress is sound, that we are going in the right direction, and that the high standards of the profession, both technical and ethical, are not sacrificed for speed. In these days of a life and death struggle there may be some criticism if our attention is diverted, even momentarily, from the first and great job in hand-to win the war, but in view of the importance of our forests, both as providing most necessary sinews of war for the struggle and by reason of the important part they will play in the aftermath, I venture tonight to predict to you, as specialists in the maintenance, preservation and cultivation of the forests, that you will be called upon to plan and direct a big job in those days, and I suggest that you take warning from those who did not prepare for War and that you prepare for Peace. 
I speak then, tonight, to the caretakers of Canada's Forests,-the architects of our country's future forest policy. Your blueprint covers a field of operations of about 770,000 square miles of productive forest lands which contain on its accessible areas about 170,000 million cubic feet of timber. Our annual crop amounts to about 10,000,000 cords of wood of which about 25 per cent is exported and the remaining 75 per cent is used in about 100 mills making pulp and paper products in Canada. Add to this an annual cut of about $51 / 2$ billion feet of logs for thousands of saw mills big and small, and other forest products and you have an annual crop which has a value of around $\$ 400$ million dollars. This is the income which trees bring to the people of Canada. On the long range view your task, of course, is to conserve the capital stock against destruction and depletion and by proper silvicultural practices to insure an annually increasing crop sufficient for the mounting industrial demands of the country and to provide the necessary exports to support foreign exchange balances. A country cannot buy unless she sells and the events of the past few years have taught us that the world has become too small for a nation to live unto itself and that international neighborliness and good feeling is dependent, at least to some extent, upon the flow of international trade.

In preparing a set of blueprints for the future we realize at once that they must fit in on a background of state economics as well as be adjustable to the currents of trade and available export markets. Here at home our history and traditions have been as individualists. Our generation, for the most part, glory in the achievements of their family forebears who came, with pork and beans and a little cornmeal, and made their way with no assets whatever except a pair of hands and an unconquerable spirit of determination and initiative and who taught their sons to do likewise if they would conquer in the world. That was the school a great many of us were brought up in and it is not difficult to understand why so many, even of this generation, find it hard to follow the profound changes which chang. ing conditions have brought about in our Government institutions and are apt to be critical and skeptical over the adoption of measures which restrict the liberty of the individual and centralize more and more authority in Government by the creation of a multiplicity of Government Departments. However, judging by the almost universal approval of public opinion which greeted the establishment of the Wartime Price and Wage Control Board measure, one is inclined to question whether we will ever be able to entirely forget the theories of National housekeeping we are being taught today and it is a poor commentary on our economic system which led a keen observer and student of Canadian affairs to state to a Canadian audience about a year ago that it was only since the momentum of war activity absorbed the unemployed, that he noticed in his travels across Canada a sense of individ. ual security among a large proportion of our population and he reminded his audience that to many Canadians "Our War was their Peace and Our Peace is their War". The absorption back into our system of production and distribution of the thousands of Canadians who are serving in the military forces or are associated in some way with the war effort would seem to be a problem which almost staggers the ingenuity of our wisest and will cer- 
tainly require a plan of rehabilitation of national character and scope. In this connection cne is amazed to learn that, with a war time yearly expenditure of $\$ 2,800,000,000$ and after three Canadian War Loans have soaked up presumably all the available loose change not required in business trading, the Savings accounts in our Canadian banks at the close of last month were only $\$ 52,000,000$ less than they were just previous to the last Victory Loan in June, 1941, and at the close of that Loan the low mark still was $\$ 1,490$,000,000 . That would seem to lend support to the theory that, in a country such as Canada, if money can be found by taxation and borrowed from with. in when it is required to defend ourselves from the enemy without in time of war, surely there must be ways and means of finding the money to spend on constructive projects within our country in time of peace, and I do submit that if our Canadian leaders and people could be induced to exert the same spirit of Canadianism in solving our peace problem which they have displayed in tackling our war job, this country could proceed with many waiting projects and enlist the services of Canadian brains and labor without throttling the initiative of the pioneer or robbing him of his fair reward for his venture.

On the outset visibility is poor and currents of trade and export markets are obscure during the present chaos, but at least one definite development has emerged-that a great many raw material producing countries are becoming highly industrialized and not dependent, as formerly, for their finished goods on the older industrial countries of Europe and North America. In view of this significant fact, and bearing in mind the phenomenal increase in industrial investment within Canada itself since the outbreak of the war and the demands which it will make on our raw materials, we would be well advised to have always in mind, in projecting our plans, the tested principle that efficient methods and highest technical skill can be depended upon to count in the long run to pay good dividends.

I remember being very much impressed by an address I heard once from one of Canada's leading citizens, in which he declared that if a nation is to survive and endure, its national character must be built on a foundation of virtue first, then wisdom and lastly skill, pointing out the weakness of the German philosophy which depends entirely upon skill. Therefore, in building this young nation, while we see to it that the virtues of the home and religion are retained as the cornerstone of the nation, in formulating a forest policy for Canada, you will first be wise before you are skillful by laying stress on a fundamental which you will point to as being primary to other branches. For as one engaged in the forest industries of Canada I unhesitatingly say that the basis of a Canadian Forest policy should be Forest Protection.

To a gathering such as this, it is hardly necessary to point out how absolutely vital the forests are to Canada's future well being. While we can truthfully say that trees mean life, the utilization and conversion of Canada's Forest products is so linked up with every phase of our economic life that there is hardly any section of the population, urban or rural, which is not touched in some way by the fortunes of forest industries. Nor is it neces- 
sary to remind you of the recreational and health-giving attributes of the forests and their effect upon the character and social life of our people. They are the source of the fishing stream, the delight of the angler, and the haunts of the wild game and the birds, the joy of the sportsmen. These values are not measured in dollars and cents but generations of a nation of people bred in and beside the woods carry the imprint of their strength. In 1906, the first Canadian Forest Convention under the auspices of the C.F.A. was held at Ottawa under the chairmanship of the late Sir Wilfrid Laurier, who at that time in most moving and eloquent language appealed for measures and methods to stop the awful conflagrations which were destroying great areas of forest land each year. While protective measures have been put in force and there is an awakening, Canada is still burning up and in this enlightened day and age millions and millions of feet of her best timber becomes prey each year to the devastations of fire. The Canadian Forestry Association since 1900, and with it in recent years, the Quebec Forestry Association under the capable leadership of Mr. Omer Lussier, has, by word, letter and picture, preached the gospel of forest protection believing that by the power of Education the people and the youth of our land would become forest conscious and the best results obtained. At Duchesnay in the Province of Quebec, I had the pleasure of being invited to attend a conference of woods managers and forest engineers of companies operating within the province where I heard the Minister of Lands 8 Mines, the Honourable $\mathrm{Mr}$. Cote, pledge his administration to take every practical measure to cope with the menace and prevent the destruction of the forests of Quebec by fire, and make an earnest appeal for the active co-opeartion of all present towards that goal. In the Province of New Brunswick we have made defi. nite headway, for after several conferences last year and with the active assistance and cooperation of the Honourable Mr. Pirie and the Department of Lands, we have got through to the people through several of the municipal councils which called special sessions to hear our representations. As a result the people of the Province of New Brunswick are forest conscious today in a way they never were before and forest fires in New Bruns. wick last year, while admitting a favourable season, were entirely eliminated. Fire is the greatest but not the only enemy of the forest. I have passed through the depressing experience of living in a once thriving community and within a few short years seeing it reduced to conditions of poverty because a stand of forest upon which it depended for the livelihood of its people, was laid flat by a destructive insect. Yes, surely wisdom teaches that our post-war rehabilitation should begin right now by sounding the slogan "Save the Forests".

Save the Forests, save them from Fire, save them from pests, insects or any other destructive agency that would destroy them. Trees are Canada's reserve forces and on the Home Front this message should ring across Canada from the forests of giant Douglas Fir, over the Rocky Mountains, and across the Prairies to the white pine of Ontario and spruce and hardwoods of Quebec and the Maritimes. To borrow the words of our peerless leader and distinguished Statesman, The Right Honourable Winston Churchill, "LET IT ROLL", from the leaders of government, the newspaper editor, the 
radio broadcaster, the preacher in the pulpit, the teacher in the schoolroom, at Canadian Club functions, service organizations and through every other available channel to the business executive, the worker in the bush, the man at the machine, the farmer on his wood lot, the angler on the trout stream or the hunter of wild game. To these and all Canadians, of all ranks and classes, "Let it roll." And let us realize that the hall mark of Canadian citizenship involves more than privileges-it involves sacred obligations as trustees to safeguard and preserve those bountiful resources, the heritage of our country for the use of the generations which are to follow. 